\title{
HISTOLOGI TESTIS MENCIT (Mus musculus L.) MUDA DAN TUA YANG DIBERI EKSTRAK LADA HITAM (Piper nigrum L.)
}

\section{TESTICULAR HISTOLOGY OF YOUNG AND OLD MOUSE (Mus musculus L.) THAT WERE GIVEN BLACK PEPPER (Piper nigrum L.) EXTRACT}

\author{
Septiya Reni ${ }^{1}$, M. Kanedi ${ }^{1}$, Nuning Nurcahyani ${ }^{1}$, Sutyarso ${ }^{1}$ \\ 'Jurusan Biologi FMIPA Universitas Lampung \\ e-mail : septiya01@yahoo.co.id \\ Jurusan Biologi FMIPA, Universitas Lampung \\ J. Prof.Dr. SoemantriBrojonegoro No. 1, Bandarlampung, Lampung, Indonesia, 35145
}

\begin{abstract}
ABSTRAK
Lada hitam (Piper nigrum L.) dipercaya oleh masyarakat memiliki banyak khasiat. Selain membuat penggunanya tetap sehat, lada hitam juga diduga memiliki kandungan antioksidan yang mampu menangkap radikal bebas sebagai salah satu faktor pemacu penuaan. Telah dilakukan percobaan menggunakan hewan mencit dengan tujuan untuk mengetahui pengaruh lada hitam terhadap perubahan histologi testis dan jumlah spermatozoa mencit muda dan mencit tua.Penelitian ini menggunakan 20 ekor mencit berumur 4 bulan dan 20 ekor mencit berumur 6 bulan. Masing-masing kelompok usia mencit tersebut dibagi menjadi 4 kelompok perlakuan. Kelompok 1, tidak diberi ekstrak lada hitam, kelompok 2, diberi ekstrak air lada hitam 0,3 ppt, Kelompok 3 diberi ekstrak ethanol sebanyak 0,3 ppt, dan Kelompok 4, diberi campuran ekstrak air dan ethanol 0,3 ppt. Data yang didapat dianalisis dengan Analisis Ragam (ANARA) 2 jalur (dengan $\alpha=5 \%$ ). Hasil penelitian menunjukkan bahwa pemberian ekstrak lada hitam pada mencit usia tua mampu meningkatkan jumlah spermatogonia dengan nilai rata-rata perlakuan mencapai 81,6 sel dan jumlah spermatogonia mencit yang tidak diberi perlakuan berjumlah 47,0 sel dalam 1 sayatan tubulus seminiferus. Sementara itu, jumlah spermatozoa antar setiap perlakuan tidak menunjukkan perbedaan yang nyata.
\end{abstract}

Kata kunci : mencit (Mus musculus L.), lada hitam (Piper nigrum L.), spermatogonium, spermatozoa.

\begin{abstract}
Black pepper (Piper nigrum L.) is traditionally believed to have some benefits. In addition to keep healthy for the users, black pepper is also known to have some antioxidant properties by capturing free radicals contribute to aging process. The experiment was conducted using mice with the aim to determine the effect of black pepper on histological changes of testis and the number of spermatozoa between old and young mice group. The experiments used 20 male mice aged of 4 months and 20 mice aged of 6 months. Each of the age group were divided into 4 treatment groups. Group 1 as control group, without any black pepper extract, Group 2, were given water extract of black pepper with concentration of $0.3 \mathrm{ppt}$, Group 3 were given ethanol extract of black pepper with concentration $0.3 \mathrm{ppt}$, and Group 4 were given mixture of black pepper extract either with water and ethanol with concentration of 0.3 ppt. Data were analyzed with Two-way Analysis of Variance (ANOVA) (with $\alpha=$ $5 \%$ ). The results showed that the extract of black pepper treated on old mice increase the amount of spermatogonia with an average of 81.6 spermatogonial cells compared with the untreated group (with cell number of 47,0 ) in one incision of seminiferous tubules. While the number of spermatozoa were not significantly different among groups.
\end{abstract}

Keywords : mouse (Mus musculus L ), black pepper (Piper nigrum L.), spermatogonia, spermatozoa .

\section{PENDAHULUAN}

Lada hitam dimanfaatkan oleh masyarakat sebagai bahan rempah-rempah karena memiliki aroma dan rasa yang khas. Aroma pada lada hitam disebabkan oleh adanya minyak atsiri yang terdiri dari beberapa jenis minyak terpene (Rismunandar, 1992).
Selain digunakan sebagai rempah-rempah, dalam tradisi pengobatan Ayurveda lada hitam diyakini memiliki banyak khasiat, yaitu dapat menyembuhkan beragam penyakit, membuat penggunanya tetap sehat dan panjang umur (Majeed and Prakash, 2000). 
Kajian terhadap kandungan kimia lada hitam menunjukkan bahwa tanaman ini mengandung bahan aktif seperti phenolic amides, phenolic acids, dan flavonoid yang bersifat antioksidan sangat kuat (Meghwal and Goswami, 2012). Antioksidan merupakan senyawa yang mampu mencegah kerusakan oksidatif secara bermakna yang disebabkan oleh radikal bebas (Halliwell and Whiteman, 2004).

Radikal bebas merupakan salah satu faktor pemacu proses penuaan. Penuaan (aging) adalah proses akumulasi berbagai perubahan pada sel dan jaringan sebagai akibat pertambahan umur. Proses akumulasi tersebut berakibat pada peningkatan risiko munculnya penyakit dan kematian. Selain itu, penuaan juga mengakibatkan kemunduran sistem imun dan penurunan kemampuan organisme dalam beradaptasi terhadap lingkungannya (Troen, 2003).

Proses penuaan yang terjadi pada pria ditandai dengan menurunnya fungsi organ reproduksi dan terjadinya kerusakan sel-sel spermatogenik. Menurut Wibisono (2001), cekaman panas pada testis dapat menyebabkan fragmentasi total dan berakibat pada kerusakan jaringan testis yang menyebabkan kegagalan proses spermatogenesis, sedangkan fragmentasi parsial berpengaruh terhadap spermatozoa yang dihasilkan.

Kerusakan sel-sel spermatogenik oleh faktor radikal bebas dapat dicegah dengan mengkonsumsi makanan yang mengandung antioksidan (Droge, 2002). Salah satu bahan pangan yang mengandung antioksidan adalah lada hitam (Piper nigrum L.). Untuk menguji kandungan antioksidan yang terkandung di dalam lada hitam, maka dilakukan penelitian dengan menggunakan hewan uji mencit (Mus musculus L.) jantan yang diberi ekstrak lada hitam dengan parameter yang diamati berupa jumlah spermatozoa dan spermatogonia mencit tersebut.

\section{BAHAN dan METODE}

\section{Pembuatan ekstrak lada hitam dan peracikan pakan}

Lada yang digunakan merupakan lada hitam yang diperoleh langsung dari petani buah lada di provinsi Lampung. Lada dipilih yang bernas lalu dikeringkan kemudian diekstraksi dengan metode maserasi menggunakan dua macam pelarut, yaitu ethanol dan air.

Masing-masing ekstrak kemudian ditambahkan pada pa-kan mencit dengan komposisi $0,3 \mathrm{~g}$ dalam setiap $1 \mathrm{~kg}$ pakan lalu dicetak kembali. Pakan dicetak membentuk batangan dengan panjang 4-5 cm dan diameter 0,5-1 cm, kemudian dikeringkan. Pakan inilah yang diberikan pada mencit hewan uji selama 3 bulan.

\section{Pemeliharaan dan perlakuan ekstrak}

Mencit yang digunakan sebagai hewan uji adalah 20 ekor mencit jantan yang berumur 4 bulan dan 20 ekor mencit jantan yang berumur 6 bulan. Pada tiap umur mencit dibagi menjadi 4 kelompok.

a. Kelompok kontrol tanpa penambahan ekstrak lada hitam

b. Kelompok dengan perlakuan ekstrak air lada hitam dengan dosis $0,3 p p t$ (PA)

c. Kelompok dengan perlakuan ekstrak ethanol lada hitam dengan dosis 0,3 ppt (PE)

d. Kelompok dengan perlakuan ekstrak air dan ethanol lada hitam dengan dosis 0,3 ppt (PC)

Masing-masing kelompok terdiri dari 5 ekor mencit yang dipelihara dalam 1 kandang yang terbuat dari plastik berukuran $40 \times 20 \times 15 \mathrm{~cm}$. Mencit uji dipelihara selama 3 bulan sehingga pada akhir penelitian usia mencit tepat 7 dan 9 bulan. Dalam penelitian ini mencit usia 7 bulan dianggap sebagai mencit usia muda dan mencit usia 9 bulan dianggap sebagai mencit usia tua

\section{Pembuatan preparat testis}

Testis difiksasi dengan menggunakan $\mathrm{HCl} 0,01$ $\%$, selanjutnya dilakukan tahapan pembuatan preparat dengan metode parafin dan pewarnaan Hematoxylin \& Eosin (H\&E).

\section{Perhitungan jumlah spermatogonia}

Histologi testis diamati di bawah mikroskop binokuler dengan perbesaran 400 kali, kemudian difoto untuk dihitung jumlah spermatogonianya pada satu tubulus seminiferus. Pemilihan tubulus seminiferus dilakukan secara acak pada setiap preparat.

\section{Perhitungan jumlah spermatozoa}

Perhitungan jumlah spermatozoa pada epididimis dilakukan menurut Soehadi dan Arsyad (1983) yaitu dengan cara meletakkan organ epididimis sebelah kiri diambil pada cawan petri yang berisi eosin, kemudian bagian proximal cauda dipotong sedikit dengan gunting lalu ditekan dengan perlahan hingga sekresi cairan epididimis keluar dan tersuspensi dengan eosin. Suspensi dihomogenkan kemudian diambil sebanyak $10 \mu \mathrm{l}$ dan diamati dengan menggunakan hemositometer. Jumlah spermatozoa per kotak dihitung pada bidang a, b, c, d, dan e (Gambar 1). Hasil perhitungan dimasukkan ke dalam rumus perhitungan jumlah sperma/ml dengan rumus:

$$
\text { Jumlah sperma }=\mathrm{N} / 2 \times 10^{5} \mathrm{sperma} / \mathrm{ml}
$$




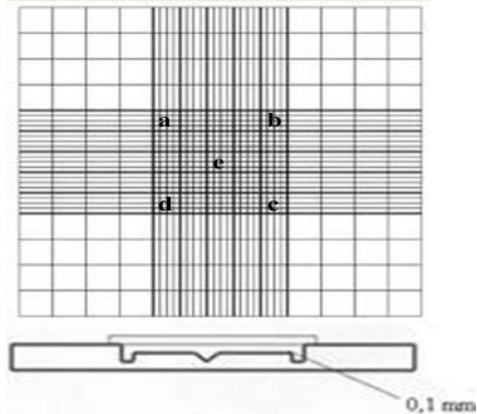

Gambar 1. Kamar Hitung pada Haemositometer (Sumber: Zaneveld dan Polakosski, 1986)

\section{Analisis data}

Data yang diperoleh dari perhitungan berupa jumlah spermatogonium dan jumlah spermatozoa dianalisis menggunakan ANOVA (analysis of variance), dilanjutkan dengan uji BNT (Beda Nyata Terkecil) dengan taraf signifikasi 5\%.

\section{HASIL dan PEMBAHASAN}

\section{Jumlah spermatogonia}

Hasil perhitungan perbandingan jumlah spermatogonia, antara mencit usia muda dan mencit usia tua disajikan dalam Tabel 1.

Tabel 1. Perbandingan jumlah spermatogonia mencit muda dan tua setelah diberi perlakuan ekstrak lada hitam.

\begin{tabular}{ccc}
\hline \multirow{2}{*}{ Perlakuan } & \multicolumn{2}{c}{ Rata-rata total jumlah } \\
& spermatogonia (sel) \pm SD \\
\cline { 2 - 3 } & Usia muda & Usia tua \\
\hline $\mathrm{K}^{*}$ & $77,80 \pm 4,20$ & $47,00 \pm 5,24$ \\
$\mathrm{PA}$ & $68,20 \pm 11,21$ & $78,20 \pm 10,32$ \\
$\mathrm{PE}$ & $79.60 \pm 9,18$ & $88,80 \pm 7,98$ \\
$\mathrm{PC}$ & $70,60 \pm 7,66$ & $77,80 \pm 4,43$ \\
\hline
\end{tabular}

Keterangan : Tanda bintang $\left(^{*}\right)$ pada perlakuan menunjukkan adanya beda nyata pada taraf signifikansi 0,05 antara kelompok mencit muda dan mencit tua.

$\mathrm{K}$ : Kelompok kontrol, tidak diberi ekstrak lada hitam

PA : Diberi ekstrak air

PE : Diberi ekstrak ethanol

PC : Diberi ekstrak air dan ethanol

Pada perbandingan antara kelompok usia tidak terdapat beda nyata antara jumlah spermatogonia mencit kelompok usia muda dengan mencit kelompok usia tua yang telah diberi perlakuan ekstrak lada hitam, tetapi pada kelompok kontrol terlihat sekali adanya beda nyata. Hal ini menunjukka bahwa pemberian ekstrak lada hitam mampu mengurangi penurunan jumlah spermatogonia mencit usia tua dari jumlah spermatogonia mencit usia muda.
Perbandingan jumlah spermagonia mencit usia muda antara kelompok perlakuan tidak menunjukkan adanya beda nyata, namun pada kelompok mencit usia tua terlihat adanya beda nyata antara jumlah spermatogonia kelompok kontrol dengan kelompok perlakuan dengan pemberian ekstrak lada hitam. Peningkatan jumlah spermatogonia mencit usia tua pada kelompok perlakuan ekstrak lada hitam diduga merupakan efek dari senyawa antioksidan yang terdapat pada ekstrak lada hitam. Senyawasenyawa antioksidan dari ekstrak lada hitam yaitu senyawa flavonoid, asam fenolat dan amida fenolat. Gulcin (2005) melaporkan bahwa ekstrak air dan ethanol dari lada hitam memiliki aktivitas antoksidan yang kuat

\section{Jumlah spermatozoa}

Hasil perhitungan perbandingan jumlah total spermatozoa mencit, antara mencit usia muda dan mencit usia tua disajikan dalam Tabel 2.

Tabel 2. Perbandingan jumlah spermatozoa antara mencit muda dan tua pada kelompok kontrol dan kelompok yang diberi ekstrak lada hitam

\begin{tabular}{|c|c|c|}
\hline \multirow[t]{2}{*}{ Perlakuan } & \multicolumn{2}{|c|}{$\begin{array}{c}\text { Rata-rata total jumlah } \\
\text { spermatozoa (juta/ml) } \pm S D\end{array}$} \\
\hline & Usia muda & Usia tua \\
\hline $\mathrm{K}$ & $20.96 \pm 5.49$ & $13.92 \pm 4.79$ \\
\hline PA & $17.53 \pm 9.48$ & $19.60 \pm 6.33$ \\
\hline PE & $16.35 \pm 4.28$ & $21.48 \pm 21.22$ \\
\hline PC & $17.20 \pm 2,82$ & $21.20 \pm 2.52$ \\
\hline $\begin{array}{l}\text { Keterangan : } \\
\text { : Kelompok } \\
\text { PA : Diberi eks } \\
\text { PE : Diberi eks } \\
\text { PC : Diberi eks }\end{array}$ & $\begin{array}{l}\text { air lada hitam } \\
\text { ethanol lada hit } \\
\text { air dan ethanol }\end{array}$ & ak lada hitam \\
\hline
\end{tabular}

Perbandingan rata-rata total jumlah spermatozoa mencitusia muda antara kelompok kontrol dengan kelompok perlakuan dapat dilihat pada Tabel 2.

Dari hasil uji statistik dengan menggunakan ANOVA, tidak terlihat adanya beda nyata antara jumlah spermatozoa mencit tua dengan spermatozoa mencit muda. Hasil uji statistik ini juga menunjukkan bahwa tidak ada beda nyata antara jumlah spermatozoa mencit kelompok kontrol $(\mathrm{K})$ dengan spermatozoa mencit kelompok perlakuan dengan penambahan ekstrak lada hitam (PA, PE dan PC). Hal ini menunjukkan bahwa pemberian ekstrak lada hitam dengan dosis 0,3 ppt belum mempengaruhi jumlah spermatozoa mencit sebagai hewan uji. Meningkatnya usia maka jumlah radikal bebas di dalam tubuh akan meningkat (Pangkahila. 2007). Pada pria radikal bebas dapat mengganggu proses spermatogenesis salah satunya menyebabkan kerusakan membran spermato- 
zoa akibat terbentuknya lipid peroksida pada membran tersebut dan lama kelamaan spermatozoa akan mati yang nantinya akan menurunkan jumlah spermatozoa. Hasil penelitian yang dilakukan oleh Agarwal et al. (2005) menunjukkan bahwa pemberian senyawa antioksidan berupa vitamin C mampu menetralisir radikal hidroksil, superoksid dan hidrogen peroksida dan mencegah aglutinasi sperma, selain itu antioksidan juga mampu meningkatkan jumlah sperma in vivo pada laki-laki infertil.

\section{KESIMPULAN}

Dari hasil penelitian dapat disimpulkan bahwa:

1. Perbedaan umur mencit jantan (muda dan tua),memperlihatkan beda nyatapada jumlah spermatogonia,namun tidak terdapat beda nyata pada jumlah spermatozoa.

2. Ekstrak lada hitam mampu menghambat penurunan jumlah spermatogonia, namun tidak mempengaruhi jumlah spermatozoa pada mencit

3. Jumlah spermatogonia mencit jantan usia tua yang diberi ekstrak lada hitam meningkat secara nyata jika dibandingkan dengan yang tidak diberi ekstrak lada hitam.

\section{DAFTAR PUSTAKA}

Agarwal, A., Prabakaran S., and Said T. 2005. Prevention of Oxidative Stress Injury to Sperm. Journalof Andrology. 26(6):54-60.

Droge, W. 2002. Free Radicals in The Physiological Control of Cell Function. Journal of Physiology. Review. 82. :47-95.

Gulcin, I. 2005. The Antioxidant and Radical Scavenging Activities of Black Pepper (Piper nigrumL.)Seeds.International Journal of Food Sciences and Nutrition. Vol. 56, No. 7:491-499.

Halliwell B, Whiteman M. Measuring. 2004. Reactive Species and Oxidative Damageln Vivo and Cell Culture.International Journal of Pharmaceutical Sciences and Research; Vol. 142:231-55.

Majeed and Prakash L. 2000. The Medicinal Uses of Pepper. International Pepper News. Vol.25, No. 1:23-31.

Meghwal, M. and Goswami K. 2012.Nutritional Constituent of Black Pepper as Medicinal Molecules.ArticleReview 1: 129. doi:10.4172/scientificreports. 12.

Pangkahila, W. 2007. Memperlambat Penuaan, Meningkatkan Kualitas Hidup. Anti Aging Medicine.Cetakan ke-1. Buku Kompas. Jakarta.
Rismunandar. 1992. Rempah-rempah Komoditi Ekspor Indonesia. Sinar Baru. Bandung.

Soehadi, K., Arsyad K. 1983. Analisis Sperma. Airlangga University Press. Surabaya.

Troen B. 2003. The biology of aging.Mount Sinai. Journal Medica. Vol 70:3-22.

Wibisono, M. 2001. Pemanfaatan Vitamin C untuk Meningkatkan Jumlah Spermatozoa pada Mus musculus yang Dipapar Gelombang Ultrasonik. Jurnal Media Medika, Fakultas Kedokteran. Juli-September 2002.Universitas Brawijaya No.3 (20).

Zaneveld dan Polakosski. 1977. Techniques of Human Andrology. Dalam Zaneveld. 1986. Short Course; Male Reproduction/ Andrology and Non-Hormonal Contraception:19. Chicago. 